\title{
LXIX. On the beds immediately above the chalk in the counties near London
}

\author{
James Mitchell LL.D. F.G.S.
}

To cite this article: James Mitchell LL.D. F.G.S. (1836) LXIX. On the beds immediately above the chalk in the counties near London, Philosophical Magazine Series 3, 9:55, 356-360, DOI: 10.1080/14786443608649014

To link to this article: http://dx.doi.org/10.1080/14786443608649014

册 Published online: 01 Jun 2009.

Submit your article to this journal

Џ Article views: 2

Q View related articles $\square$ 
limestones, or the manner and circumstances under which they have been produced, as that has been done in so masterly a style by Dr. Hibbert, in his memoir on the Burdiehouse limestones: and the fact of the occurrence of freshwater limestones in the carboniferous group has become so firmly established, that what remains to be done is a careful investigation of the districts where the coal measures are exposed, in order to trace how far they extend, and what varieties of remains of animal life they present. The ultimate result, I have no doubt, will be a vast mass of evidence respecting the circumstances under which the coal measures generally have been deposited, and a considerable additional light will thus be thrown upon the origin and formation of the coal itself. Thus, as the small mountain rivulet, receiving new force and power from the most insignificant sources, gradually rolling on towards the wide ocean, becomes the broad and noble river, so each new fact, however trifling in itself, will give a slight but additional impetus to the stream of knowledge which is fast bearing us forward to the ocean of some grand theory of geology: the collection of facts thus slowly accumulated will one day be grasped by some comprehensive and master mind, -a new Newton will arise and place in our hands one universal outline of the laws that have guided and still guide nature in her unvarying progress.

Hall of Manchester Natural History Society,

W. C. Williamson. August 12th, 1836.

LXIX. On the Beds immediately above the Chalk in the Counties near London. By James Mtrcheld, LL.D., F.G.S.*

THERE is a description of flints found in beds immediately over the chalk, and below the sand, in all the places where these strata are seen to meet, in the counties of Surrey, Kent, Essex and Hertford, and may very probably also be found in other counties, also in similar situations.

There are sixteen localities in which $I$ have seen this flint on the south side of the Thames, and five on the north side.

The pits on the south side are:

Pit close to Croydon in Coomb Lane.

Road to Tunbridge beyond Farnborough.

Pit on the right of the road from Bromley to Chiselhurst.

Pit in a vale on the south side of Elmstead near Chiselhurst.

- Communicated by the Author. 
Loam-pit hill near Lewisham.

Mouth of the Cavern on the side of Blackheath hill.

Pit in Old Charlton on the south side of the Woolwich road.

Great pit at New Charlton.

Cliff opposite Woolwich dock-yard.

pit at Erith.

Three pits near the bank of the river Cray near Crayford.

Pit on the north side of the churchyard at Dart

Trenches dug for forming a common sewer near Gravesend, on property belonging to Mr. Rosier.

The entrance to the tunnel of the Thames and Medway canal at Higham.

On the north side of the Thames the localities observed are, Purfleet, a pit on the west side and another on the east side of Belmont Castle near Grays, and a pit on the east side of Grays; also a pit at George's Farm near Hertford.

A similar stratum is seen at Newhaven in Sussex, and the same flints bave been seen in other counties, but not in their original site.

At Purfleet the name given to these flints is iron flints. The bed in which they are found is generally about eight or nine inches deep, seldom above a foot, and consists of a reddish clay with an abundance of oxide of iron. Scarcely any sand can be got from this clay by washing. It is stuck quite full of flints. Some of these flints are very small, not exceeding an inch in length; but the greater portion are three or four inches long, and some much longer. They are round, and terminating in a point at each end, and on the whole in form not unlike a cucumber. Some however are of a triangular form. The exterior is covered with a rough black crust, which is found to be a combination of silex and oxide of iron. When broken by the hammer the oxide of iron is found to penetrate about a quarter of an inch all round, and there are frequently streaks of iron further in the interior. The body of the flint is black, but decidedly distinct from the dark blue flints found in chalk. The fracture is conchoidal, but these flints, though not unmanageable, do not yield flakes in any direction so readily as the chalk fints. When burnt in the fire the exterior crust becomes reddish, and the rest of the flint is of a dirty white colour, not nearly so bright and beautiful as the porcelain substance made by burning chalk flints. It is exceedingly difficult, with ever so great caution, to get them burnt without cracking and flying in pieces. Such of these flints as have been exposed to the atmosphere have become partially decomposed immediately under the black crust.

I have been informed by two gun-flint makers that such 
flints afforded the best sort of gun-flints for gentlemen's fowling-pieces; but being less easily made than the gun-flints from the chalk flints, and the material being less abundant, they were more expensive. On account of the presence of so much iron they are totally useless in the porcelain manufacture; but I have been informed that on one occasion as many as ten tons were obtained at the bottom of the great pit at Erith which were so pure as to be saleable for that purpose. Few specimens are large enough for building, and therefore their chief use is for road-material.

An irregular broken line of flints of this description is to be seen at the sides of the deep cuttings at the entrance of the tunnel of the London and Birmingham railway beyond Watford. Great diluvial action has taken place, and the upper surface of the chalk is torn and ridged; and if, as we have no reason to disbelieve, there was a bed of sand here over the chalk, we must in consequence suppose that it has all been carried away. But the flints peculiar to such beds are seen above the solid chalk, and below the diluvial matter, scattered along on both sides of the cutting.

I have seen such flints in considerable quantity in the fields on the east side of Margate, in the Isle of Thanet, and likewise in Norfolk and Suffolk.

In the pit on the south side of Elmstead near Chiselhurst, and in the pit on the south side of the Woolwich road, there are in the same beds with these fints innumerable small fragments of the same kind of flint, but not in the least rounded, and with sharp edges; which proves that in these localities there had been agitations, and that the flints had readily been broken into fragments.

The most extensive section of this stratum which $I$ have ever seen is at Newhaven in Sussex. It extends upwards of a mile along the top of the cliff, and the peculiar flints may be collected all along the foot of the cliff: They are well known to the fishermen who collect chalk-flint boulders for the Staffordshire potteries, and are carefully avoided. One of these men said to me that he knew that one of them would be enough to spoil a hundred pounds' worth of good material. I found a cast of an Echinus there, but not a particle of the shell remained upon it.

There is another and very distinct variety of ffint, which may be seen in some of the pits in the same bed in which the preceding variety has been found. I may mention the pit at old Charlton near the Woolwich road, in the trenches dug by Mr. Rosier near Gravesend, and on the south side of Elmstead near Chiselhurst; also at Purfleet. 
These flints are very large and of very irregular shape. They bear some resemblance to very large blocks of flint frequently seen towards the top of some chalk-pits. When broken with the hammer, however, they present instead of the deep dark blue of the chalk flints a grayish surface, in many parts whitish, as if composed of silex differently granulated, and probably mixed with argillaceous or other matter. When burnt in the fire they appear still more decidedly different in appearance. There are streaks of oxide of iron diffused near the surface, and in many instances throughout the whole mass. The whole flint has not been formed at once, but one part has aggregated after another, and the divisions are very perceptible to the eye.

In the face of a fractured flint of this species is frequently seen one dark black piece surrounded with a mass of grayish flint, and sometimes more than one such dark piece. But sometimes also there is a grayish piece of flint surrounded by black flint: many divisions in curved and generally circular lines are perceptible.

When burnt in the fire these flints separate into pieces, leaving almost smooth surfaces on both sides at the places of separation. These flints are totally useless for gun-flints or for the porcelain manufacture, but are excellent for building.

Such flints are well known at Northfleet, being found very abundantly in the loam immediately over the chalk-pits near to Gravesend. But the watery action there has been so considerable that there is merely a thin stratum of diluvial matter and vegetable mould over the chalk; so that although I have known of them for several years past, it was not until a few months past I discovered them in situ in the places already stated. They are not unfrequently seen in the fields in the counties round London where the chalk comes up near to the surface. If a name be given to them it might be the gray iron flint.

In this flint I have found at Northfleet abundance of Echini, the Echinocorys, Scutatus, Conulus, and Spatangus, generally much crushed, and the shells themselves totally gone, probably corroded and destroyed by the oxide of iron.

Mr. Parkinson, in a paper published in the first volume of the Geological Transactions, has remarked the difference of the casts found in the gravel from the casts found in the chalk, and contends that they are of different origin. I have no doubt they are the same species as those in the chalk, and that this bed which I have attempted to describe is the original habitat of the fossils to which he refers. 
The BEDS of SAND immediately above these flints are of different kinds.

At New Charlton it is a fine white sharp sand, and is used in the foundries about London. The sand at Old Charlton is almost as good, but it is chiefly used for sanding floors. At Erith, Purfleet, and Grays it is only fit for ballast. But in the trenches dug by Mr. Rosier, and at Elmstead, it is quite different. On taking samples of this sand to London and washing it, and examining it when dry, I found it to be sand exactly the same as that which is well known near London as brickmakers' sand, which is exceeding soft when felt between the fingers, and is used for sprinkling the brickmakers' moulds to prevent the adhesion of the clay. It is obtained for that purpose from above the mud opposite to Woolwich, and off Crayford Point, and is, no doubt, washed down by the rain and brought into the Thames by the rivers Cray and Darent from the districts through which they run.

In respect of the chalk immediately below these beds of flint, in most of the localities examined the surface is perfectly level, even, and unbroken; and it is not furrowed and indented as some observers have represented the upper surface of chalk always to be.

That opinion must have been formed from the circumstance of the chalk, in almost all places where it is near the surface of the ground, having suffered much diluvial action; and from chalk-pits generally being opened, from a motive of saving expense, on the sides of hills, where there is little top surface to be carried off. In the pit at Elmstead it is, however, different from the other localities. There the chalk is cut into ridges, the hollows of which are filled with these flints and clays coloured with iron: which is a proof that in one instance at least the chalk may have suffered diluvial action before the formation of these flints and of the beds of sand over them; but being only one locality out of twenty-one, it shows that the general rule is otherwise.

LXX. Mr. J. SaXton on his Magneto-elcctrical Machine; with Remarks on Mr. E. M. Clarke's Paper in the preceding Number.

To the Editors of the Philosophical Magazine and Journal. Gentremen,

I REGRET that I am called upon to notice a very disingenuous article in the Number of the Philosophical Magazine for October. A reader unacquainted with the progress 